\title{
O BRASIL DOS BACHARÉIS: UM DISCURSO LIBERAL UDENISTA
}

\author{
Jorge Gomes de Souza Chaloub
}

é professor do Departamento de Ciências Sociais do Programa de Pós-Graduação em Ciências

Sociais (PPGCSO) da Universidade Federal de Juiz de Fora (UFJF). Juiz de Fora, MG, Brasil.

E-mail: jchaloub84@gmail.com

Orcid: 0000-0002-7990-4496

http://dx.doi.org/10.1590/0102-263304/107

A nota tirada ao povo

Pelo Estado quitandeiro

Rotulado Estado Novo.

Quem lhe porá um paradeiro?

- o Brigadeiro!

Brigadeiro da esperança,

Brigadeiro da lisura,

Que há nele que tanto afiança

A sua candidatura?

- Alma pura!

(Manuel Bandeira, LiRA do Brigadeiro)

\section{Introdução}

O bacharel é um dos mais célebres personagens da história política brasileira. Ele evidentemente não se destaca sozinho, quase sempre amparado por outros tipos, como o militar, o homem de negócios, o fazendeiro ou o jornalista, mas por certo, ao longo do difícil percurso de construção 
do Estado nacional brasileiro, tem papel de destaque. Não é caso, aliás, de especificidade nacional. Weber (2004, p. 76) destaca como a atuação dos "juristas formados em universidades [...] determinou, de maneira dominante, toda a estrutura política" e foi fundamental para a "progressão no sentido de uma forma estatal racional”. Se os militares são os mais evidentes responsáveis pelos solavancos que rompem com a legalidade, muitas vezes para garantir regularidades outras, durante muito tempo coube ao bacharel a preponderância na administração dessa ordem, mesmo que não raro eles também tomassem parte nas tentativas de golpeá-la.

A República de 1946 foi a primeira experiência democrática brasileira de larga escala. Ainda existiam significativas restrições ao sufrágio, como a vedação do voto aos analfabetos, que alcançavam 54\% da população em 1945, decisão que impedia, na primeira eleição do novo regime, a participação de mais da metade da população adulta nas eleições. A cas264 sação do registro do Partido Comunista do Brasil (PCB), em 1947, marca a exclusão de significativa tendência política do cenário legal, em evento que, sem dúvida, também abala o caráter democrático do regime. É inegável, por outro lado, que a ampla expansão do sufrágio - os 1,5 milhão de 1933 seriam 7,5 milhões de 1945 e chegariam a 18,5 milhões em 1962 (Soares, 2001, p. 318) - e a relevância dos processos eleitorais como instrumentos de organização do poder político, sem falar na inédita possibilidade de expressão política por parte das classes historicamente excluídas, apontavam para a centralidade do demos na instituição do regime, em cenário que, não obstante as imperfeições, pode ser classificado como ao menos parcialmente democrático. Estamos diante de um evidente processo de democratização (Brown, 2015; Tilly, 2006), mesmo que ainda não fosse alcançado o sufrágio universal.

Habituados a outros terrenos, os bacharéis brasileiros se viam diante de novas lógicas e práticas políticas, com 
consequências que muitas vezes fugiam a seus mais arraigados hábitos e perspectivas. A democracia não apenas aumentava o número dos que influem nas questões de Estado, mas transformava a própria natureza da política, agora conduzida por imperativos estranhos, ao mais tranquilo mundo das oligarquias e das ditaduras. Nenhum partido da nova ordem seria tão diretamente afetado por essas transformações como a União Democrática Nacional (UDN). Muitas vezes representada como o "partido dos bacharéis", ela tinha dentre suas principais figuras importantes juristas, muitas vezes catedráticos em grandes faculdades de direito, conhecidos por suas atuações nas tribunas parlamentares e pela influência na determinação da linha política udenista. Apenas na "banda de música", destacam-se nomes como Afonso Arinos de Melo Franco, Milton Campos, Bilac Pinto, Adauto Cardoso e Prado Kelly, intelectuais públicos cuja influência transcendia em muito os limites do partido, com marcada presença nos maiores debates da época. A República de 1946 não pode ser compreendida sem a atenção a essas personalidades.

A atuação pública desses bacharéis alcançava os mais diversos campos, para além das fronteiras do mundo jurídico, como suas marcas nos debates sobre temas como o monopólio estatal de petróleo e a remessa de lucros bem demonstram. O ideário liberal da época, que tinha na UDN seu principal representante, deles recebeu grande parte das suas teses. Se o feitio desse liberalismo só encontra sua plena inteligibilidade nas disputas de então - incompreensíveis às ideias sem referência à sua conjuntura -, ele é também fruto das influências intelectuais dos seus formuladores. A adequada análise desses atores requer, nesse sentido, grande atenção ao papel que o mundo jurídico desempenhava em sua formação e atuação política.

$\mathrm{O}$ artigo pretende dialogar e contribuir com a ampla e sofisticada bibliografia sobre o liberalismo no Brasil. Desse 
modo, seja por meio do explícito debate ou da influência em relação à formulação das suas principais questões, foram relevantes para o trabalho tanto as obras responsáveis por mais amplos panoramas do ideário liberal no Brasil - casos de Florestan Fernandes (2006), Luiz Werneck Vianna (1976), Roberto Schwarz (2000) e Wanderley Guilherme dos Santos (1978) - quanto os estudos clássicos sobre a UDN, como os de Maria Victoria Benevides (1981), Octávio Dulci (1986) e Fernando Lattman-Weltmann (2005).

Este artigo reconstrói as principais teses e influências intelectuais dos bacharéis udenistas, tratando do pensamento político de personagens como Afonso Arinos, Bilac Pinto, Aliomar Baleeiro, Milton Campos e Prado Kelly. Para a tarefa, são mobilizados escritos jurídicos, memórias, discursos parlamentares e outras reflexões que permitam caracterizar esse pensamento que é voltado à ação, mas que também é expressão de uma visão de mundo transcendente à disputa política 266 mais imediata. O texto se divide em três partes. Na primeira, trata da autoimagem dos bacharéis, em oposição à categoria antagônica dos juristas, e distingue dois tipos ideais: os conservadores e os modernizantes. A segunda seção aborda o tipo de liberalismo dos bacharéis, visto como chave para a compreensão das suas trajetórias. Por fim, o trabalho se concentra nos argumentos dos autores sobre as relações entre elites e direito, com o intuito de melhor compreender o sentido da sua missão política e das suas trajetórias ao longo da República de 1946.

\section{Entre bacharéis e juristas}

A ampla presença de bacharéis no parlamento e na burocracia pública não era, como já dito, fenômeno recente na história brasileira. O pensamento político brasileiro é em grande parte produzido por intelectuais que tinham na reflexão jurídica um dos principais eixos da sua interpretação de país, com exemplos que se alastram por distintos campos ideológicos. Não faltava aos bacharéis da UDN a 
percepção de que integravam essa longeva linhagem de pensadores-juristas, sempre presente em seus discursos e textos. Uma análise mais apurada sobre o tema demanda, todavia, a consideração dos diversos tipos de vínculos entre os intelectuais e o mundo do direito, ou seja, dos muitos possíveis significados da caracterização de um ator político como bacharel. Ao menos três modelos se destacam.

O primeiro se caracteriza pelo recurso ao diploma de bacharel como meio de distinção social e ingresso na elite política. As faculdades de Direito são um tradicional percurso rumo aos cimos do poder no Brasil (Adorno, 1988; Carvalho, 1980; Coelho, 1999; Engelman, 2006). Muitos dos que trilham esse caminho não se distinguem, todavia, pelos traços usualmente vinculados aos bacharéis na política brasileira. Se o título é requisito para a carreira política, não é pelas habilidades teóricas ou retóricas adquiridas no mundo jurídico que eles constroem sua imagem pública. A formação em ciências jurídicas certamente influencia parte da sua trajetória, mas não ocupa lugar central em suas biografias. Dois dos maiores inimigos dos bacharéis udenistas, Getúlio Vargas e João Goulart, são exemplos dessa estirpe.

Outro tipo ideal é o político marcado pela formação forense em seu estilo retórico, mas que não cultiva o gosto pelas fórmulas e argumentos jurídicos. $\mathrm{O}$ encadeamento das teses e as modulações de voz apontam para o ensino das faculdades de Direito e para a persona do advogado, mas o conteúdo dos argumentos passa longe dos códigos e manuais. É claro que as formulações retóricas determinam, em certo sentido, as ideias e ações, de modo que a "exposição jurídica" acaba por conformar em alguns aspectos muitos dos seus argumentos. O lugar secundário dos temas jurídicos na determinação em suas relações sociais e vida pública os torna, todavia, distintos do último tipo, analisado nas próximas linhas. Alguns dos mais célebres bacharéis pessedistas, como Gustavo 
Capanema e Tarcílio Vieira de Melo, exemplificam com perfeição esse modelo de homem público.

Há, por fim, os atores que têm na expertise forense elemento central para sua afirmação no campo político, a determinar um traço essencial de suas figuras públicas. $\mathrm{O}$ conhecimento jurídico tem, nesse caso, papel central em suas concepções de mundo. Não faz sentido para esses personagens pensar a política como autônoma perante o campo jurídico, já que o conceito de Direito adotado não se constrói contra a história ou a sociologia, mas os toma como necessariamente vinculados. Esses são os bacharéis udenistas, personagens que tanto marcaram a imagem e a trajetória do partido. O estudo do repertório por eles mobilizado é, nesse sentido, fundamental para a compreensão da forma pela qual o pensamento jurídico influencia a inserção pública dos atores e conforma sua interpretação de país. O campo do Direito oferece, entretanto, inúmeros caminhos para a compreensão 268 da realidade, o que torna necessário não apenas delimitar a presença da retórica jurídica, mas também expor quais ideias forenses informavam seu pensamento e prática política e explicitar qual era, afinal, seu conceito de direito.

Algumas figuras centrais da política brasileira compõem a galeria dos seus antecessores, dentre os quais se destaca o vulto de Rui Barbosa, referência constante dos bacharéis udenistas e razão de crítica dos seus opositores. Famosa, nesse sentido, é a frase de Otávio Mangabeira para Afonso Arinos, reproduzida nas memórias do segundo, ao se deparar com a grande biblioteca particular do mineiro: "Estamos perdidos! Político com livro em casa nunca deu certo! Quem tinha mais livros era o pior político: chamava-se Rui Barbosa" (Franco, 1965, p. 42). O comentário não revela apenas posição pessoal do célebre líder baiano, mas replica uma corrente crítica aos bacharéis udenistas, comumente retratados, dentro e fora do partido, como juristas descolados da realidade nacional e inaptos para a vida política, já 
que mais preocupados com seus tratados jurídicos do que com as prementes questões que confrontavam a classe política. A distinção entre bacharéis e juristas, elaborada nas memórias de Afonso Arinos, busca responder a esse ponto, repaginando a imagem dos bacharéis dos quais Arinos era um dos mais destacados líderes - como comprova sua longa permanência à frente das lideranças do partido e da oposição, entre 1951 e 1958 - e o mais importante intelectual.

Há, sem dúvida, uma nuança bem marcada entre os conceitos de bacharelismo e de juridicismo no Brasil. São ambos filhos dos mesmos pais, o Império acadêmico e discursivo (muito mais profundo e autêntico, no entanto, do que parecem acreditar certos observadores apressados) e a tradição luso-coimbrã agasalhada nas Faculdades de leis de São Paulo e Pernambuco. O juridicismo evoluiu para uma espécie de abstração científica, um certo gênero de clericalismo (no sentido de Julien Benda) que nos deu Teixeira de Freitas, Lafayette Rodrigues Pereira, Clovis Bevilacqua e mesmo Tobias Barreto ou Pedro Lessa, cujos temperamentos ferventes não eliminaram aquela irresistível tendência à formulação teórica, que os incompatibilizava, como os demais, com a vida política. Um traço do juridicismo é, aliás, este: a inadaptação à política partidária militante, apesar da evidente paixão política de homens como Lessa e Tobias. Já o bacharelismo é outra linhagem, tão diferente como os Orleans dos Bourbons. O bacharelismo é a técnica jurídica aplicada especialmente à realidade política. Não é teórico, sobretudo não é abstrato ou filosófico. O maior dos bacharéis brasileiros é Rui Barbosa, cuja incapacidade para a filosofia e a teorização tem sido tantas vezes salientada. (Franco, 1965, pp. 48-49)

Bacharéis, não juristas, seriam de acordo com essa tipologia figuras como o próprio Afonso Arinos, Milton Campos, Prado 
Kelly, Aliomar Baleeiro, Bilac Pinto, Adauto Lúcio Cardoso, dentre outros. Em suma: a ala dos bacharéis da UDN. Para estes atores, o Direito não figuraria como abstração filosófica, indiferente à realidade, mas seria antes técnica jurídica aplicada diretamente à realidade política. Mais do que homens das leis, os bacharéis se integrariam à conhecida estirpe de homens da política, do Estado, responsáveis por aproximar os abstratos e intrincados textos legais das demandas sociais. Personagens ligados ao mundo estatal, sem dúvida, mas distantes do ideal de uma burocracia moderna, que separa o campo da administração do da política e requer aos funcionários públicos a neutralidade. A política é antes arte que ciência, que tem no Direito sua linguagem privilegiada e no senso de realidade seu norte. Mais do que transformar o mundo, cabe à política permitir que os homens melhor se adaptem a ele. $\mathrm{O}$ bacharel se distingue como hábil estadista por sua capacidade de se adaptar ao ritmo da sociedade e prever, antes dos demais, as transformações que 270 se delineiam no horizonte.

Os juristas, por sua vez, privilegiariam a formulação intelectual ante as imposições da política, amantes da sequência necessária das fórmulas teóricas que não perecem em meio à contingência do mundo. A "paixão política”, como resposta dos atores às intempéries do mundo, não é incompatível com a persona, mas atua ao lado da inadaptação à política partidária militante. O jurista é antes de tudo um homem da ciência, no caso a ciência do direito, compreendida em chave filosófica como sequência de pressupostos lógicos, e não sociológicos ou históricos. A política ocuparia lugar menor, limitada às convicções interiores e subjugada aos ditames da razão jurídica. Tal relativo distanciamento do mundo tornaria o jurista mais propenso a transformá-lo. A precedência das ideias ante a realidade o impele, muitas vezes, a uma ação menos conformista perante as imposições da ordem social, não desejoso de responder a elas, mas ansioso por modificá-las. O raciocínio de Arinos atribui ao 
jurista maior inclinação ao novo, em contraste com a tendência à conservação por parte dos bacharéis:

confirmo para mim mesmo uma expressão [...] a do conservadorismo dos bacharéis, em contraste com o espírito inovador (seja no sentido progressista seja no reacionário) dos juristas. Porque isto? O jurista é homem de maior capacidade indutiva, tende a formular, a criar o direito, a extraí-lo da observação do complexo social. Por isto vê este complexo no seu dinamismo histórico, e o espírito que anima é sempre aberto às mudanças, às inovações da realidade vital, seja na direção evolutiva (como Tobias), seja na orientação reacionária (como Campos). Já no bacharel o traço de espírito marcante é a agudeza dedutiva. Ele tende a aplicar e não a formular o direito; ou antes, é homem mais da lei que do direito. Porém a lei, de certo modo, é apenas a cristalização de uma experiência social já vivida, quero dizer, já passada. Daí o bacharel ser levado, por hábito e por gosto, à defesa das fórmulas consagradas, à imutabilidade das estruturas, à solidariedade com os sistemas criados, em uma palavra - sem o menor sentido pejorativo - ao conservadorismo, que é, em geral, bem distinto do reacionarismo. (Franco, 1965, p. 49)

O bacharel é um conservador, "homem mais da lei que do direito", mas a lei vista como imutável e representada como cristalização de uma experiência social já vivida, não como instrumento de transformação da realidade. A proverbial resistência dos bacharéis udenistas à mudança social - tão bem representada pela defesa da integridade da Constituição de 1946 contra as reformas de base do governo João Goulart - ilustra sua concepção conservadora do direito, visto como a mais sólida barreira às instabilidades do mundo moderno, já que "continua a ser a única força social capaz de encaminhar tais transformações no sentido do menor 
sofrimento e do maior benefício para os homens" (Franco, 1961, p. 172). Fundamental para a resistência a uma ditadura que teve como um dos seus protagonistas - especialmente em sua fase mais repressora - um jurista, Francisco Campos, o bacharelismo revelava, segundo o bacharel Arinos, em um momento de crítica e autocrítica, sua face conservadora e até mesmo reacionária quando se defrontava com as forças da transformação, que inevitavelmente emergiam em um regime democrático. $\mathrm{O}$ mineiro parte dessa perspectiva para atacar a conduta do seu partido às vésperas do Golpe de 1964: "Isto explica perfeitamente porque a UDN, cuja participação foi tão sanguínea e juvenil na fase em que o Brasil precisava restaurar o Estado de direito, se mostra hoje tão à margem, tão incapaz, quando o que precisamos é renovar o direito do Estado" (Franco, 1965, p. 49).

A construção dessa imagem dos bacharéis não é esforço solitário de Arinos. Aliomar Baleeiro retorna ao mandato de 272 Rui Barbosa à frente do Ministério da Fazenda para demonstrar que as criticadas condutas do bacharel baiano, como o encilhamento, eram antes guiadas por uma superior astúcia política, que submetia o saber técnico ao interesse público e à estabilidade do novo regime. Rui não era um economista, mas um estadista à frente do ministério (Holanda e Chaloub, 2017):

Rui Barbosa [...] em verdade a dirigia com profundo sentido político, que serve de medida de coordenação entre as várias medidas características de sua rápida passagem pelo poder [...] O problema econômico e financeiro, embora o estudasse profundamente à luz doutrinária, equacionou-se, pra ele, em termos políticos: qual a solução admissível com o mínimo de inconveniências no momento em que, pela força, novo regime se implantara, provavelmente sem apoio de toda ou da maior parte da opinião pública. (Baleeiro, 1952, pp. 74-76) 
Rui estaria distante da imagem do jurista ensimesmado, que encantado pelos livros resolveu importar fórmulas e instituições estranhas à realidade brasileira. $\mathrm{O}$ baiano antes integrava a estirpe dos grandes homens de Estado, que não se restringiam ao saber livresco ou à representação de interesses específicos, mas agiam politicamente em meio às imposições das conjunturas. Próximo a figuras como Hamilton, Gladstone e Churchill, Rui honra a "tradição do Brasil Imperial, que fez passar pelo Ministério da Fazenda alguns dos seus mais luminosos homens públicos" (Baleeiro, 1952b, p. 74).

Segundo esta argumentação, os bacharéis udenistas teriam se mostrado hábeis nos desafios típicos do governo em suas principais experiências administrativas. Responsável por um dos grandes momentos políticos do grupo, quando à frente do Governo de Minas, entre 1947 e 1951, Milton Campos (1951, p. 267) expõe, em claro discurso, como antes o encantavam mais os desafios da prudência e da maleabilidade do que a firme adesão a ideias preestabelecidas, já que "o sistema pode ser um compromisso para professores e filósofos, mas não pode ser mais do que uma orientação para os dirigentes, cujo compromisso é a realidade, excluído da expressão o odioso sentido maquiavélico". Aparentemente mais difícil, a defesa abnegada de posições doutrinárias de princípio era mais fácil do que o difícil exercício da moderação: "o meio termo é uma posição de coragem [...] O ponto extremo é mais cômodo, porque oferece uma definição precisa e dispensa as constantes revisões que a realidade suscita" (Campos, 1951, p. 267).

O grande problema de alguns dos bacharéis udenistas passava, todavia, pela dificuldade de responder às vertiginosas mudanças da sociedade brasileira. Habilidosos dentro dos parlamentos e fóruns estatais, eles tinham dificuldade de atuar em meio à nova era da política de massas. Mais do que uma política, faltava uma sociologia que desse conta 
dos processos de mudança social em curso. Em texto escrito em momento próximo ao fim da República de 1946, Afonso Arinos destaca: "O declínio da UDN é sociológico e não político, e corresponde, no fundo, à prisão dos seus homens a essa espécie de legalismo antijurídico, que é o bacharelismo" (Franco, 1965, p. 49). Faltavam a esses liberais respostas institucionais eficientes, amparadas em reflexões sociológicas, ao processo de massificação da política brasileira. Claro que havia transformações perante certo ideário liberal da Primeira República, que teve em Rui Barbosa seu grande protagonista, como as adesões ao tema do planejamento, marca da época, e o debate em torno de questões de caráter social bem demonstram. Permaneciam, todavia, as dificuldades em se apropriar de forma original dessas ideias, de modo a recriá-las de forma claramente distinta da experiência varguista. Como o Rui do texto sobre a questão social (Barbosa, 1952) - que segundo Afonso Arinos antes 274 as aceitava como imposições da época que se entusiasmava com as transformações sociais (Franco, 1965, p. 48) - eles percebiam as mudanças, mas não eram capazes de transformá-las em plataforma política.

O problema afeta sobretudo aqueles que chamaremos de bacharéis conservadores, ciosos por filtrar a mudança a partir dos valores e medidas do passado. Personagens como Afonso Arinos, Milton Campos e Prado Kelly percebiam as transformações do tempo, mas buscavam resposta, em que pese eventuais esforços distintos, em meio ao repertório longamente consolidado por parte das elites políticas brasileiras. Os apontamentos sobre a necessidade de inovações acabavam subalternos diante de caminhos já conhecidos, que apontavam para a ordenação da sociedade a partir do manejo do Direito por elites virtuosas e repelia inovações que não passassem pelo filtro das tradições. $O$ futuro e o presente eram organizados a partir do passado, mas não se tratava, nos termos de Mannheim (1959), de um simples 
tradicionalismo, repetição inconsciente de velhos hábitos, já que os bacharéis construíam uma clara interpretação do devir histórico e do processo de modernização brasileiro que merecia, assim, o epíteto de conservadorismo. Caso distinto é o dos bacharéis que merecerão o título de modernizantes, os quais conciliarão esse olhar para as tradições e o passado com um esforço de modernização do Direito e uma perspectiva que, mesmo entusiasta da ação política, valoriza menos a virtude dos ocupantes do poder. Dentro dessa categoria, podemos mencionar nomes como Bilac Pinto e Aliomar Baleeiro.

Ideólogos anteriores aos bacharéis conservadores e modernizantes - como Oliveira Viana, Francisco Campos e Azevedo Amaral - foram capazes de responder, em sua diversidade, de modo mais eloquente às demandas do tempo, propondo uma inclusão subalterna das massas urbanas, ou, nas palavras de Werneck Vianna (1976, 2001), uma "expansão autoritária da república”. Os bacharéis, por sua vez, igualmente refratários às soluções "de baixo" e críticos ao Estado Novo, regime do seu grande antípoda, se viam em difícil posição, muitas vezes compelidos a combater o ditador sem negar as heranças da ditadura. Para compreender esses limites, é necessário olhar para a visão de mundo desses personagens - o liberalismo que em parte os definia -, que se mostra decisiva para sua ação na cena política.

\section{O liberalismo dos bacharéis}

A farta presença do discurso jurídico é uma das peculiaridades da tradição liberal brasileira. Não que o liberalismo clássico não dedique muitas linhas à argumentação e categorias do Direito. Conceitos centrais do pensamento liberal - como as ideias de "Estado de direito", "governo da lei" e "sujeito de direito" - pertencem ao léxico jurídico, já que cabe ao direito, nesse ideário, a garantia da esfera de atuação do indivíduo e da sua proteção perante o poder 
estatal. Seja no contratualismo lockeano ou no utilitarismo de Bentham, passando pela distinção entre as liberdades antiga e moderna segundo Benjamin Constant, o pensamento liberal demanda ao discurso jurídico elementos para construir sua visão de mundo (Audar, 2009). A perspectiva dos "direitos" constitui, como bem coloca Pocock (2003), uma destacada linhagem do pensamento político moderno.

Mesmo ante tais importantes ressalvas, ainda é inegável a especificidade de certo liberalismo brasileiro, sobretudo pelo papel relativamente subalterno que o conceito de mercado ocupa no seu discurso. São evidentes, por um lado, os vínculos entre a perspectiva liberal do Direito e da economia, já que as construções jurídicas liberais quase sempre partem de uma concepção antropológica voltada para o interesse e da presença do conceito de mercado como ideal de organização social, para além do campo da economia (Rosanvallon, 2002). Nesta tradição não exclusivamente 276 brasileira, mas de grande sucesso nestas terras, enquanto o mercado ocupava um papel mais discreto na ordenação social - raros os que, até 1946, o escolhiam como princípio basilar de organização do público - o Direito ganha enorme força, visto como instrumento mais relevante para a atuação do Estado e organização da sociedade. O liberalismo toma forma juridicista, não por ignorar a sociedade na qual atua, afinal estamos diante de bacharéis, não de juristas, mas por julgá-la ainda despreparada para uma ordenação por suas próprias forças e interesses. Ainda distante de uma ordem capitalista e competitiva, o país poderia constitui-la por meio do Direito, caminho para o moderno. Tal precedência da forma jurídica não importa em um discurso único, mas leva a uma forma liberal que tem por característica central a enorme importância e o papel fundamental do Estado. Surge um liberalismo que enreda a dimensão do interesse em dinâmica mais ampla, à moda do interesse bem compreendido de Tocqueville (2001). 
A interpretação de que o país ainda estava distante do pleno funcionamento da ordem capitalista produz um ideário no qual os traços e valores aristocráticos predominam sobre o esforço pela construção de uma ordem burguesa. O papel dos bacharéis é central nessa empreitada, com o Direito a desempenhar a função de principal linguagem da sua prática e reflexão política. A política econômica do partido, por exemplo, era em grande parte formulada pelos catedráticos de Direito Tributário e Economia Política das faculdades de Direito, caso de Aliomar Baleeiro e Bilac Pinto, com influência de juristas americanos contemporâneos e franceses do início do século XX, como Léon Duguit e Maurice Hauriou (Chaloub, 2017).

O argumento está presente de forma explícita em trabalhos clássicos sobre o liberalismo brasileiro, como os de Luiz Werneck Vianna (1976) e Maria Victoria Benevides (1981). Ambos ressaltam a centralidade do Direito na tradição liberal brasileira e o papel dos bacharéis em sua trajetória, seja como protagonistas na construção do Brasil pós-1930 - como bem ressalta o autor de Liberalismo e sindicato no Brasil-, seja como líderes da UDN, como bem retratado no clássico livro sobre o partido. Benevides, entretanto, exacerba o papel do liberalismo econômico no discurso dos bacharéis udenistas, em interpretação que não considera o central papel econômico do Estado em seu discurso. ${ }^{1}$

Se os argumentos jurídicos perpassam a reflexão do partido sobre as mais diversas áreas, há que se ressaltar que o Direito não era visto como técnica fechada em si mesma, mas como arte do bem administrar a sociedade, sem, contudo, em nenhum momento dela se apartar. Os bacharéis não sucumbem a qualquer perspectiva do jurídico como sistema lógico, característica dos juristas, mas o compreendem como processo social de ordenação dos conflitos, o

\footnotetext{
${ }^{1}$ O tema foi detidamente debatido em Chaloub (2017).
} 
qual nem sempre se confunde com a lei. O Direito era o meio que distinguia a opção liberal das outras, autoritárias, e permitia cumprir o objetivo central do liberalismo. Os bacharéis não pretendiam organizar "por baixo" a vida jurídico-política, mas almejavam, sobretudo, disciplinar novas forças sociais emergentes. ${ }^{2}$

O Estado predomina nas duas vertentes do liberalismo dos bacharéis, temorosos os liberais de qualquer projeto que deixe o interesse excessivamente livre e possa implicar maior participação das massas. A transformação por meio do protagonismo popular, com toda a sua imprevisibilidade, pode levar à destruição de antigas relações de comando e privilégio, em narrativa preocupante aos olhos dos que estavam há muito acostumados a certa ordem. A ruptura com a estrutura agrária e com os mecanismos de coerção da força de trabalho urbana (Fernandes, 2006), passos necessários para a construção de um desenvolvimento liberal à ameri278 cana (Vianna, 2004), não frequentavam os discursos e propostas da maior dos liberais, que se mostravam receosos ante as possíveis consequências de uma mudança social excessivamente profunda e sem maiores possibilidades de controle.

Sobretudo no liberalismo conservador, o utilitarismo dá lugar a imperativos de harmonia social e a um sentido de equilíbrio, marcas de um ideário hostil ao conflito. Se o perigo do comunismo sempre frequentou o discurso liberal (Motta, 2002), ele ganha forma especialmente virulenta na argumentação udenista. Não há, por outro lado, grande simpatia pela lógica do interesse e do mercado, visto como exógeno à realidade brasileira. Através de um diagnóstico que se atém às características nacionais e destaca o caráter ainda

\footnotetext{
2 Anos mais tarde, em depoimento ao Centro de Pesquisa e Documentação de História Contemporânea do Brasil (CPDOC), Arinos assim interpreta a missão liberal: "Se você depreender o liberalismo da sua significação econômica, que foi a que prevaleceu no século passado, vai notar que é um processo de compreensão de todas as surgências. Chamo de surgência a manifestação de forças sociais que não estão ainda disciplinadas nem acolhidas pelo aparelho de Estado" (Franco, 1983, p. 56).
} 
precário da nossa ordem burguesa, o liberalismo dos bacharéis defende uma visão politizada da economia ou, para recorrer a um conceito largamente utilizado por Raymundo Faoro (2000), um capitalismo politicamente orientado. O discurso liberal se aproxima de um modelo de "modernização conservadora” (Fernandes, 2006). É exemplar, nesse sentido, o discurso de Arinos, proferido em 16 de janeiro de 1953 na Câmara dos Deputados, sobre o perfil mais adequado para os cargos de ministro da Fazenda e presidente do Banco do Brasil:

Ocorre, porém, Sr. Presidente, que a nossa formação e a nossa conjuntura atual são particularmente diversas das que se verificam na grande república do norte. Os EUA são, por excelência, uma nação capitalista, uma nação que surgiu com o capitalismo, em função do capitalismo e por causa do capitalismo. [...] O Brasil, com uma formação completamente diversa, Sr. Presidente, está ainda longe de ser um país capitalista. [...] A verdade é que os usos mais fecundos do nosso passado demonstram, Sr presidente, que melhor andou gerida a coisa pública nos setores entregues aos problemas financeiros e econômicos, quando os gestores dessa coisa pública não eram pessoalmente os representantes [...] das grandes forças econômicas da empresa privada. (Franco, 1953, n.p.)

A argumentação não se limita às particularidades locais, mas vai além e atinge, sobretudo nos bacharéis conservadores, o próprio modelo de civilização capitalista e utilitária. Mais do que indesejável para o caso brasileiro, um mundo regido pelo interesse e pelo cálculo instrumental entra em conflito com todas as crenças e perspectivas desses bacharéis. Nas palavras de Milton Campos (1972, p. 110): "Porque não será republicano considerarmos a Pátria uma sociedade anônima, o governo uma gerência, a política um negócio 
e a imprensa uma empresa. [...] a vida pública não amealha recompensas nem capitaliza os juros da sua benemerência”. O liberalismo ganha tintas ibéricas (Barboza Filho, 2000; Vianna, 2004), elogioso de um tipo antropológico bem distante do indivíduo movido por benefícios, no lugar do qual se recupera o conceito de pessoa (Mauss, 2003), que irredutível à generalização característica da forma individual possibilita distinções qualitativas entre os homens e evita certa igualdade abstrata, afeita à mediocridade e inerente ao individualismo.

Os argumentos ganham feições próximas ao arielismo, importante tradição intelectual latino-americana que se funda na crítica à política de massas, sendo refratária tanto ao mundo da utilidade e do mercado quanto às soluções de cunho socializante. Os bacharéis conservadores emulam, guardadas as diferenças de contexto, os espíritos de Rodó e Eduardo Prado, entusiastas de uma visão de mundo que 280 reclamava um caminho diverso para as elites pressionadas a optar entre as vias capitalista e socialista. Caso fosse necessária a escolha, não resta dúvida do lado ao qual adeririam afinal nada pode ser pior que os males do comunismo - mas é também evidente que a adesão aos pressupostos civilizatórios do capitalismo era definitivamente difícil para os partidários desse liberalismo, cultor de uma antropologia completamente diferente da abraçada pelo mundo do mercado. Se há um individualismo saudável para o desenvolvimento nacional ele é antes o dos liberais franceses do XIX: "O individualismo, como filosofia política, como construção jurídica do século passado era uma manifestação de crença nas possibilidades de aprimoramento e de evolução do homem" (Franco, 1965, pp. 160-161).

Os bacharéis conservadores apontam os males das sociedades de massas, responsáveis pelo ocaso da "virtude pessoal": "O que se reclama é a recuperação do homem que se despersonalizou no informe, e contra a massificação do homem cumpre 
promover a humanização da massa" (Campos, 1972, p. 48). Ventos elitistas perpassam o liberalismo dos bacharéis, porém ele não se resolve por diretas referências de sangue e família. Se é possível se falar na defesa de uma aristocracia, como governo dos melhores, ela passa pela virtude e capacidade de compreender e atuar politicamente, pelo primado dos "estadistas", tal como os define Arinos. ${ }^{3}$ Estes seriam os mais aptos para o exercício da política e do governo, distintos por suas qualidades pessoais dos demais indivíduos e, especialmente, dos caudilhos, que ludibriam as massas e impedem o sucesso dos estadistas (Lattman-Weltmann, 2005).

Homens de Estado, os estadistas também comungariam do realismo, avessos às abstrações características dos juristas. Não é necessário, ou mesmo corriqueiro, que os estadistas sejam bacharéis, muitas as formações e perfis possíveis para a definição de um grande líder. O encantamento dos bacharéis udenistas com a liderança de figuras fortes, inspiradoras para construção do tipo ideal do estadista, mas dissonantes de vários atributos do bacharelismo, é um bom exemplo desse fato. Vale mencionar a veneração ante o símbolo maior do partido, o brigadeiro Eduardo Gomes, e os constantes elogios a figuras como Juarez Távora, também candidato udenista em um pleito presidencial, ambos homens em muitos sentidos distantes da visão de mundo dos bacharéis. Em prefácio às memórias de Távora, Arinos destaca: "Com as figuras [...] de Juarez Távora e Eduardo Gomes encerrou-se, pelo menos pelo futuro previsível, um ciclo no entanto rico da História Militar Brasileira - o ciclo do heroísmo. Juarez e Eduardo serão, provavelmente, os últimos heróis brasileiros no campo política-militar" (Franco,

3 O comentário de Milton Campos (1972, p. 95) sobre Raphael Magalhães expõe bem o ponto: "Há fidalgos que, para se fazerem conhecer como tais, precisam trazer no bolso a prova autêntica da sua linhagem. A nobreza de Raphael Magalhães documentava-se com a simples presença e dispensava os brasões lustrosos que tanto envaidecem a talufaria e a fatuidade [...] não é isso que importa, e sim o traço aristocrático do espírito; e este era de grande relevo em Raphael Magalhães. 
1976, p. XII). Não estamos diante, adverte o bacharel, do herói mítico, mas do herói histórico, que representa "a elevação do homem a símbolo, ou expressão viva dos valores sociais e morais coletivos dominantes na sua época, e nada tem a ver com a mitificação ou a deificação" (Franco, 1976, p. XII). O elitismo dos bacharéis os leva a aceitar a representação do líder carismático, caso ele não afronte os mais importantes pilares da sua visão mundo.

Trata-se de um liberalismo de elites virtuosas, capazes de dar sentido para o mundo amorfo das massas. Para além da defesa de pautas políticas concretas, importa a afirmação de uma visão da política e do mundo. O "estilo" é fundamental para o modo como esses atores percebem e atuam em sua época, já que condiciona de forma decisiva sua perspectiva sobre as massas, a representação política e a atuação do Estado. Os bacharéis udenistas, protagonistas da cena política, com suas vozes a ressoar nas tribunas parlamenta282 res e na imprensa, representavam a clara permanência de certa vertente liberal, com grande sorte em outros tempos. O liberalismo não é percebido como forma de organização social, que organiza o mundo a partir da proteção e do estímulo à livre atuação do indivíduo, mas enquanto "estado de espírito”. Um ainda jovem Milton Campos (1972, p. 9) já desenvolvia esse ponto com precisão:

o liberalismo mineiro existe efetivamente, não como partido ou doutrina política, mas como índole, temperamento e vocação. Não é o liberalismo das frases sonoras, atmosfera da incultura e veículo da demagogia. Para esse, realmente, é possível que não exista mais lugar no mundo moderno. Nem é o romantismo político, cujas abstrações fogem ao quadro das realidades. Nada mais característico do temperamento mineiro que o senso de realidade. 
Mais velho, já governador de Minas Gerais, ele dá a forma final ao seu liberalismo conservador, que expõe não apenas uma percepção individual, mas o sentimento de toda uma geração, que inclui nomes como Afonso Arinos e Prado Kelly: "A ideia liberal deixa, assim, de ser uma filosofia ou um sistema, para conservar-se como estado de espírito" (Campos, 1972, p. 110). O liberalismo não pode ser resumido a opções políticas ou ideias, mesmo que tenha nelas elementos fundamentais, mas se define por uma postura perante o mundo, um "saber proceder" análogo à ideia de virtude aristocrática, mesmo que não dê maior importância, todavia, a traços hereditários. As elites não se distinguem pela origem, mas pela capacidade de "ordenação dos 'valores' em que seu poder se baseia” (Kelly, 1977, pp. 64-65). Estão nos valores e na moral os meios e fins do seu predomínio e da sua própria definição enquanto grupo. Importam, sobretudo, "índole, temperamento e vocação", já que é o espírito, composto por esses elementos, que dá sentido ao mundo da política.

Não é coincidência que sejam estes os traços que distinguem o estadista, tal como concebido por Arinos enquanto líder capaz de encantar - por meio de um carisma de tipo peculiar, composto por tintas aristocráticas - um mundo desencantado pela razão instrumental, linguagem vulgar passível de ser declinada por qualquer um, inclusive pelos ditadores e caudilhos, mais preocupados com a precariedade do poder do que com as superiores artes do governo. A quantidade precisaria passar pelo crivo da qualidade para que haja uma real democracia. Há uma direta relação entre um efetivo governo democrático e a prevalência política das verdadeiras elites, tendo em vista - segundo ficção historiográfica de Arinos - a natural rejeição desses grupos às soluções de força: "Getúlio nunca chegou em vida a atrair as elites, naturalmente hostis aos processos políticos antidemocráticos" (Franco, 1968, p. 112). 
A construção da ordem não passa, nessa perspectiva, pelo dissenso de interesses de indivíduos ou facções, mas pela composição harmônica das vontades, em perspectiva liberal que recusa qualquer tipo de conflito, exceto quando vê ameaçada a ordem que busca instaurar. Há, por esse olhar, um interesse nacional a ser construído e mediado, através da ponderação e da habilidade política das elites. O dissenso não produz boa ordem, mas age contra o bem comum. Mesmo um documento como o Manifesto dos Mineiros, texto de crítica ao Estado Novo e face pública de uma conspiração que buscava derrubar a ditadura de Vargas, se preocupava todo o tempo em destacar seu caráter não faccioso - já que "não é um documento subversivo; não visamos agitar nem pretendemos conduzir" - e avesso às paixões mais violentas do conflito, tudo isso num "tom de conversação em família, família numerosa, porém unida e solidária", que fala "à comunidade mineira sem enxergar 284 divisões ou parcialidades, grupos correntes ou homens" (Franco, 1946, pp. 103-107).

Minas aparece como representação geográfica desse liberalismo. Há que se considerar a origem dos autores, muitos deles mineiros, mas a construção desse imaginário não se restringe a isso, já que decorre da ideia do estado montanhês como síntese dos interesses nacionais genuínos, imunes às imposições das inúmeras centralizações forçadas que marcaram a história brasileira e culminaram em Vargas. Para o argumento, interessa menos o efetivo lugar geopolítico do Estado que sua construção como um elogio desse centro harmonioso (Arruda, 1990), que, todavia, não se furtava a resistir à opressão - como nas constantes menções à Inconfidência Mineira e a Teófilo Otoni - quando via seus valores e estilo de vida ameaçados. Minas era ao mesmo tempo pátria desse liberalismo, como origem geográfica e espiritual, e futuro a ser construído e espalhado para o país. 
O elogio da harmonia e da moderação vem necessariamente acompanhado de uma perspectiva de política limitada a alguns atores, destinados a exercer esse fardo, que não convém ou interessa à maior parte da população. Como em longa tradição do pensamento político (Aguiar, 2013; Balibar, 1997), atribui-se às massas a inconstância e a passionalidade, características incoerentes com o governo, que demandaria a ponderação típica dos grandes homens, talhados para a liderança. O perigo é quando o povo, inapetente para decifrar os melhores representantes dos seus interesses, escolhe aqueles que, em vez de ajudá-lo, o traem:

O povo, por mais que se lhe diga que é a fonte do poder, não se interessa em exercê-lo. Entrega-se, confiante, a líderes que o exploram e traem e que, ainda quando o representem pelas aferições imperfeitas da sua vontade, não o sentem no âmago de suas aspirações e apenas o afagam na superfície enganosa de seus equívocos. (Campos, 1972, p. 109)

A afirmação da incapacidade do povo brasileiro para o exercício consciente do voto, antigo tema do pensamento liberal e das elites política brasileiras, ganha força após a derrota - surpreendente para os udenistas - de Eduardo Gomes para Dutra em 1946 e torna-se quase onipresente nas falas do partido depois do retorno de Vargas ao poder em 1950. O discurso dos liberais encontra-se, todavia, em aparente tensão com algumas lutas do seu passado. O desenvolvimento de mecanismos de democracia formal foi um frequente e relevante tema dos principais ideólogos liberais ao longo do Segundo Reinado e da Primeira República, figurando também como argumento central para a conformação da oposição liberal crítica ao Estado Novo. O partido que se declarava como mais eminente descendente da Campanha Civilista e da Reação Republicana (Franco, 1980, p. 88), e se via como 
rebento do Manifesto dos Mineiros deveria, segundo tal linha de raciocínio, reconhecer orgulhoso os resultados da sua longeva luta. Como bem reconhecia Afonso Arinos, apesar dos problemas do sistema, as massas urbanas - ampla maioria do eleitorado, tendo em vista a vedação do voto aos analfabetos votavam livremente.

As conquistas da tradição liberal de reforma dos costumes políticos e administrativos revelavam-se, todavia, uma vitória de Pirro. As lutas de outrora não bastaram, já que o povo, incapaz de reconhecer os que melhor o representariam, acabava conduzindo ao poder os responsáveis pela opressão de ontem. Anos mais tarde, ao tratar dos partidos políticos brasileiros, Arinos expunha os problemas da última experiência democrática, da qual fora protagonista:

"A cabina indevassável e a Justiça Eleitoral são provas de que o voto é livre. Mas a consciência cívica do eleitor médio continua em atraso, nem é coisa que se possa melhorar em pouco tempo e isoladamente. Depende do progresso da instrução, o que quer dizer, do progresso geral do país" (Franco, 1980, p. 118).

A conclusão desvela, na verdade, os claros limites dos esforços pela "verdade das urnas", que tanto nas vozes liberais do início do século XX quanto nos discursos dos bacharéis udenistas pressupunham a exclusão dos muitos que não estavam aptos a desempenhar adequadamente seu papel no cenário político. As críticas ao sistema político revelam o desconforto com a emergência de figuras pouco habituadas a frequentar os salões do poder e que, por isso, acabariam por desvirtuar a natureza da cena política, ao colocar demagogos no lugar dos vocacionados à liderança.

As massas aparecem como incapazes e facciosas, dependentes, em sua minoridade, de alguém para conduzi-las. Não bastava reformar as instituições, era necessário transformar 
também os agentes que as operavam. Restava, todavia, a questão de como viabilizar tal transformação nos limites do liberalismo. Formalmente livre, o voto está na verdade agrilhoado às mais espúrias forças políticas brasileiras, os patriarcas e caudilhos, já que, com a exceção de uma "elite liberal", a plebe se vê enfeitiçada por promessas, valores e símbolos rebaixados, que impedem o país de se desenvolver:

Em virtude do sufrágio universal, a esmagadora maioria do eleitorado brasileiro vota, assim, levada por patriarcas e caudilhos. Resta uma elite diminuta, quase toda habitando as cidades de mais de 20.000 almas, a qual vota livremente, levada por suas próprias convicções. Essa elite, dadas as condições de sua formação de classe, é predominantemente liberal. (Franco, 1980, p. 56)

A ojeriza a Vargas, o caudilho por excelência, passa pela enorme incompatibilidade entre o "Brasil dos bacharéis" e o projeto político do líder gaúcho - este um eclético composto de influências - mas também se funda na repulsa à própria imagem pessoal do político de São Borja, completamente diversa do modelo de homem público cultivado pelos bacharéis. Nada mais oposto ao bacharel-estadista, homem do brilho retórico e da erudição, que vagava pelos salões do Palácio Tiradentes, mas poderia, na sua própria concepção, facilmente frequentar a Câmara dos Lordes ou a Assembleia Nacional francesa, do que o caudilho da fronteira, silencioso e calculista. Em depoimento ao CPDOC, Afonso Arinos assim recordava as impressões que Vargas lhe causava: "O Getúlio contrariava todos os nossos padrões, todos os nossos hábitos [...] Era silencioso, num meio político de oradores, de faladores. Era frio, pelo menos aparentemente, no meio de emotivos. Era um sujeito estranho" (Franco apud Camargo, 1983, p. 56). 
Os embates não se restringem às ideias ou interesses, mas atingem o próprio modelo de ator político. A oposição de Arinos entre o bacharel e o caudilho é também o embate entre tipos de homens públicos. Não à toa o combate ao homem Vargas parece por vezes tomar o centro do cenário político, como questão central a dividir a UDN e o Partido Social Democrático (PSD). O corpo pessoal de Vargas não pode, entretanto, ser percebido como oposto às questões públicas, em chave que opõe o "personalismo" às instituições ou ideais (Laclau, 2013), mas está a elas necessariamente ligado. Primeiro porque nenhum líder condensou com maior precisão os valores que organizavam os grandes embates públicos da época. Nesse sentido, não se trata de querela apenas fundada na luta de indivíduos por postos de poder, por mais que, é claro, eles importem, mas de embate que toma os líderes, como Vargas, enquanto representação de ideias, interesses e instituições. Mais do 288 que um indivíduo, Vargas é manifestação pública de uma ordenação de mundo. Além disso, para os bacharéis a oposição entre pessoas e instituições, Direito e moral, não pode ser percebida de maneira rígida. A política é um território ordenado pelas instituições, mas essas não ignoram os traços pessoais daqueles que as comandam. O personalismo frequentemente atacado é o das personalidades deslocadas em sua vocação política.

\section{Direito e as elites}

Tarefa das elites, a política opera pela linguagem do direito, instrumento capaz de ordenar o mundo e controlar os desvarios das multidões, mas essa gramática depende dos indivíduos que a conjugam. O Direito não é, aos olhos dos bacharéis, de nenhum modo neutro, já que estamos distantes do mundo das fórmulas lógicas dos juristas. Ele não apenas conforma o modo de compreender o mundo dos atores como comporta uma pluralidade de sentidos 
e disputas, pois não se pode falar de um único conceito de direito. Refletir sobre o papel do mundo forense no pensamento e ação política dos bacharéis é, nesse sentido, analisar o papel do Direito em seu discurso e investigar qual repertório o estrutura.

O mundo jurídico para os bacharéis encontra-se diretamente vinculado a outra forma de ordenação social, em contraposição à qual o Direito por vezes se define: a moral. Se as virtudes pessoais justificam a precedência na vida pública, nada mais natural que a moral, um dos componentes desse caráter virtuoso, não seja percebida como pertencente ao terreno da intimidade, mas se transforme em elemento central da política. $\mathrm{O}$ direito, nesse sentido, não se opõe à moralidade - à moda de uma tradição de positivismo jurídico que remete a Hobbes (Villey, 2008) - mas deriva seu sentido dela, elemento necessário à sua legitimidade. Mais importante que os formalismos são os valores que eles protegem, já que a estabilidade dos governos depende da sua força moral. Ao analisar, em discurso na Câmara dos Deputados, as razões da crise política que assolava o país em 1963, Bilac Pinto destaca a existência de uma "crise de moralidade" como elemento responsável pelas outras duas "crises" identificadas pelo bacharel: a "crise política" e a "crise administrativa" (Bilac Pinto, 1964, pp. 9-44). Arinos expõe com clareza suas convicções no mesmo sentido: "Uma das coisas mais idiotas que se pode imaginar é suposição de que a autoridade moral é qualquer coisa de ideal e abstrata [...] a autoridade moral é a força básica da estabilidade dos governos" (Franco, 2005, p. 10).

No lugar do mundo desencantado do utilitarismo e do interesse, que compreende o Direito como técnica de organização social capaz de conjugar as vontades de indivíduos e grupos, emerge uma sociedade organizada por princípios morais, passíveis de serem remetidos a tradições, que agem como "um fio invisível, mas atuante de orientação para o futuro" (Campos, 1951, p. 142). A tendência moral do homem, pessoa 
e não indivíduo, é o único caminho para ordenar a sociedade de forma perene, para além dos formalismos vazios:

o homem é por excelência um ser moral. Daí o erro de consequências sinistras dos que esvaziam a ordem democrática do sentido ético, atentos à organização e não à ordem, à superfície e não à profundidade, à matéria e não ao espírito, à riqueza e não à felicidade. Enganam-se esses, porque a moral está na base da política, ainda para os que supõem afrontá-la. (Campos, 1972, p. 67)

Milton Campos repele os movimentos de superfície e busca fundar a ordem legítima em bases mais profundas e perenes. A fungibilidade do indivíduo utilitário e da lógica capitalista, que sintetiza o mundo a partir da forma mercadoria, produzem um tempo que não condiz com os ideais do bacharel conservador, ansioso por um sentido 290 que ultrapasse a fugacidade das conjunturas. A adesão às formas da modernidade encontra, deste modo, suas razões em lugar alheio ao cenário moderno, buscando dotá-lo de um valor que o escapa. Não se trata, entretanto, da negação de imposições pragmáticas da política, mas do esforço por atribuir-lhes outra dimensão, encontrada apenas nos meandros da tradição, que tem no bacharel e no estadista atualizadores e intérpretes.

Se "normalmente não é a lei que cria o direito, mas o contrário é que se dá" (Franco, 1961, p. 179), em terras brasileiras, devido ao "violento desnível cultural entre o povo e as elites" (Franco, 1961, p. 131), se percebe "a contribuição poderosa das elites brasileiras e o aspecto construtivo da norma jurídica em relação ao Direito" (Franco, 1961, p. 131). Muitas são as "instituições que a lei, elaborada pelas elites, transformou em Direito para o povo" (Franco, 1961, p. 131). Distintamente dos países onde "a lei veio apenas reconhecer um fato político e jurídico 
já definido havia longos anos" (Franco, 1961, p. 131), aqui ela desempenha papel fundamental para o progresso. A existência de uma sociedade desfibrada - tema clássico do pensamento brasileiro - e de um povo inculto demandariam a firme organização da lei, já que não há um passado a ordenar o país a partir de valores compartilhados: "Além disso não temos, propriamente, passado, e, neste ponto, é tão verídico como perigoso observar que somos, realmente, um país do futuro; só do futuro" (Franco, 1965, p. 130).

O bacharel e o estadista são os agentes capazes de conter esse princípio entrópico, inerente a sociedades "sem passado" como a brasileira, ordenando os impulsos sociais e definindo os rumos do país. Nesse caso, todavia, a recusa da organização da sociedade pela via exclusiva do mercado implica o descrédito diante da grande maioria da população, à qual se nega qualquer clareza sobre os próprios interesses. Não sem motivo esse liberalismo afirma que "o tempo do liberalismo passivo já findou” (Franco, 1946, p. 108), adere com tanta tranquilidade à ideia de planejamento e diagnostica a altos brados a "inevitável transformação do individualismo jurídico em socialismo jurídico" (Franco, 1961, p. 179), o qual tem por principal marca o "planejamento democrático". Adeptos de uma postura construtivista perante a sociedade, era natural aos bacharéis a afinidade com a ideia de planejamento, termo onipresente na mais diversas correntes ideológicas da época e, por isso, marcado por grande polissemia.

Presente na perspectiva dos bacharéis conservadores, como Arinos, o planejamento ganha feições mais modernas na pena dos liberais modernizantes. O Direito ainda é visto como instrumento político de organização da sociedade, mas há um menor destaque à virtude dos governantes e uma maior 
preocupação em modernizar o aparato jurídico e o Estado. ${ }^{4} \mathrm{O}$ liberalismo não se define, nessa vertente, como "estado espírito", à moda de Milton Campos, mas enquanto instrumento de controle do processo de transformação social. Ainda há desconfiança ante o mundo do mercado, mas a distância entre o liberalismo modernizante dos bacharéis e o liberalismo econômico se dá mais em virtude do predomínio da política na organização do mundo dos bacharéis do que pelo antimaterialismo arielista, que marca os bacharéis conservadores:

A nova política intervencionista foi um rude teste a que se submeteu a eficiência do Governo. A estrutura orgânica e funcional do Estado, modelada no pressuposto do quadro econômico e social do laissez-faire, teria, necessariamente, que se manifestar inadequada para atender aos novos tipos de atuação que dele se reclamava. As funções do Estado, além de terem se ampliado sensivelmente, assumiram aspectos novos. [...] A atividade jurisdicional relacionada com os modernos problemas sociais e econômicos, para não redundar em denegação de justiça, teve que se flexibilizar pela supressão do formalismo forense, tornando-se mais econômica, mais rápida e mais bem aparelhada para a formulação de standards jurídicos. (Bilac Pinto, 1953a, pp. 250-251)

O vocabulário retirado do Direito público norte-americano, que vem a complementar a anterior influência francesa, aponta para o esforço de se adequar aos novos tempos e para uma ação política um pouco mais descolada do passado. O Direito e a política não perdem seus vínculos com a tradição, ainda presente no imaginário dos bacharéis modernizantes, mas são primordialmente vistos como instrumentos de transformação da sociedade, em chave mais

\footnotetext{
${ }^{4}$ Aliomar Baleeiro e Bilac Pinto buscaram introduzir disciplinas mais próximas do mundo econômico nas faculdades de Direito cariocas da época, inclusive como autores de nova proposta de ensino jurídico (Venâncio Filho, 2004, pp. 313-314).
} 
preocupada com o porvir. A diferença entre os dois liberalismos dos bacharéis é, deve-se ressaltar, mais uma inflexão, a qual antes produz distintos estilos de ação pública do que uma radical mudança de substância. Trata-se, afinal, de dois olhares semelhantes para a época - já que, apesar dos diversos adjetivos, todos permanecem bacharéis - que carregam, entretanto, sentidos temporais distintos, os quais levam os atores a repertórios e encontros muitas vezes diferentes.

De volta às convergências, há que se ressaltar como a identidade dos bacharéis udenistas se define em oposição ao país profundo, onde vigia uma lógica distante dos seus ideais normativos. Homens do centro, lugar de predomínio dos princípios civilizatórios, eles lidavam com os imperativos da política local, fundamentais para sua permanência enquanto representantes eleitos, como obrigação aceita a contragosto. As manifestações desse país disperso do localismo passavam pelo caudilhismo, mas não se limitavam a ele. Dentro da própria UDN, o grupo dos "chapas brancas”, por vezes chamados de "realistas", servia de contraponto aos bacharéis, com muitas vezes distantes da visão de mundo da "banda de música". Adversários costumeiros nas disputas em torno das diretrizes do partido, querelas onde não era rara a vitória dos "chapas brancas", os bacharéis tinham, por outro lado, uma profunda dependência dessas figuras, necessárias não apenas para a manutenção da UDN enquanto potência eleitoral em um país ainda predominantemente agrário, mas para sua própria eleição (Franco, 1965, p. 185).

A tensão entre essas "duas almas" não era, entretanto, exclusividade da UDN. A recente nacionalização do sistema partidário brasileiro deixava ainda frouxos os vínculos entre a política nacional e a municipal. Em estudo clássico sobre os parlamentares pessedistas e udenistas, Sérgio Miceli identifica grande semelhança de "origem social", "formação escolar" e "trajetória ocupacional". Suas diferenças decorreriam de "diferentes modalidades de inserção desses representantes no 
espaço da classe dirigente" (Miceli, 1997, p. 662). São, desse modo, antes os distintos movimentos no mundo político, por meio de interesses e visões de mundo, que as diferenças de origem social o elemento central para compreender os caminhos desses dois partidos da República de 1946.

$\mathrm{Na}$ visão dos bacharéis, como bem expõe Arinos, a grande vantagem das nossas elites sobre seus congêneres latino-americanos se deve, justamente, ao pleno domínio das mais avançadas técnicas jurídicas de organização e controle dos impulsos e volições das massas, com - segundo a concepção do autor - raros recursos a violência ou a restrições da liberdade (Franco, 1961, p. 131). O novo sempre se submete ao filtro da tradição, em dinâmica que impede rupturas mais profundas que poderiam, como nos abundantes exemplos disponíveis na história latino-americana, nos levar à anarquia. A sequência de elogios pode levar à ideia de que Arinos via as classes dirigentes brasileiras como um con294 junto de grandes homens e personalidades brilhantes. Nada mais falso. Em famoso discurso de homenagem a Joaquim Nabuco, ele destaca, por exemplo, o contraste entre a enorme figura do homenageado e seu entorno, chegando a falar do natural protagonismo de Nabuco em um "país pobre de homens como o nosso" (Franco, 1961, p. 269). As memórias do bacharel, dentre outros escritos, também carregam tom não menos crítico em relação à sua época. ${ }^{5} \mathrm{O}$ destaque dado em sua narrativa a elites, estadistas e bacharéis brasileiros não passa por seu caráter excepcional, mas decorre de dois aspectos que estruturam a visão de mundo de Arinos. O primeiro é o caráter central da ação humana e das grandes personalidades na História, o que por vezes o levava a uma historiografia próxima da de Carlyle. Se, para o autor, a compreensão da política e dos fenômenos sociais

\footnotetext{
${ }^{5}$ Há que se ponderar, entretanto, que as memórias de Arinos são redigidas, em sua maior parte, durante momento de evidente perda de influência do político mineiro.
} 
requer atenção a mudanças estruturais de maior monta, que prescindem da consciência dos agentes, é inegável a forma como a atuação e a trajetória de certos personagens é central para a fisionomia de muitas conjunturas, que são mesmo incompreensíveis sem uma devida atenção a tais figuras. Outra crença se vincula à precariedade da formação sociológica brasileira, onde o rebaixado nível cultural e intelectual do povo eleva, por contraste, os componentes das elites.

Não resta dúvida, todavia, que se deve à sabedoria das nossas elites a construção de uma "tradição mundialmente louvada de mudanças brancas" (Franco, 2005, p. 61), que garantiu, apesar de todos os percalços, a predominância da ordem ao longo da história brasileira. Tal tradição parece, entretanto, estar com seus dias contados, tendo em vista a radicalidade dos conflitos que então marcavam o país. $\mathrm{O}$ Brasil se encontrava então marcado, na visão de Arinos, pelo recrudescimento dos embates políticos e sociais, direta consequência da ampliação dos partícipes da esfera pública e da emergência de novos atores e demandas.

O diagnóstico geral entre os bacharéis era o de que o Brasil atravessava uma profunda crise, presente em diversos campos; todos, contudo, profundamente imbricados. Como no já citado discurso de Bilac Pinto (1964, p. 12), a crise é ao mesmo tempo "moral", "política" e "administrativa”, esses os principais aspectos da corrupção geral, ou da subversão irrestrita, que marcaria a sociedade brasileira de então. A anarquia reina, impulsionada pela tibieza, política e moral, do governante. Se o diagnóstico sobre a existência de uma crise generalizada na sociedade brasileira está presente nos discursos udenistas desde os primeiros anos da República de 1946, é inegável que ele ganha força nos momentos de mais intenso embate público, como em 1954/1955, 1961 e 1964. Em julho de 1963, no primeiro artigo da série que escreveu para o Jornal do Brasil, e que 
seria depois reunida em "Evolução da crise brasileira", Afonso Arinos assim construía seu diagnóstico da época:

Segundo a opinião provavelmente unânime dos brasileiros e dos estrangeiros que nos observam, nosso país está em crise, sendo que muitos se acham convencidos de que ela é a mais grave crise de toda a nossa história. [...] Dentro da tormenta, as elites, sejam por se sentirem mais culpadas, seja por terem mais consciência dos riscos, se agitam ou se apavoram, enquanto as massas populares se mantém muito mais tranquilas. (Franco, 2005, p. 27)

Os termos para identificar a natureza dessa crise ganham, entretanto, contornos diversos. Mantida a ideia de uma alteração na ordem "natural" do mundo social e político, o que torna explícita a existência de uma crise, são dois os mecanismos possíveis podem desencadeá-la: a cor296 rupção e a subversão. A corrupção quase sempre é referida ao contexto brasileiro e tem suas principais causas remetidas à permanência do getulismo, essa doença caudilhista que assola o país e contra a qual os remédios liberais da Constituição de 1946 não se mostraram eficazes. Extirpá-la é a única saída para a construção de uma ordem democrática e moderna no país, já que não há democracia possível que conviva com o mal caudilhista. A figura retórica do "mar de lama”, metáfora para a onipresença da corrupção mais identificada com Carlos Lacerda, não se restringiu às manifestações do político carioca, mas também teve lugar no discurso dos bacharéis, como bem demonstra o famoso pronunciamento do então líder do partido Afonso Arinos, clamando pela renúncia de Vargas: “[... ] seu governo é hoje um estuário de lama e um estuário de sangue; observe que os porões do seu palácio chegaram a ser um vasculhadouro da sociedade" (Franco, 1954, n.p.). O constante flerte com as Forças Armadas e o recurso a contorcionismos jurídicos, 
como a invenção de uma suposta exigência implícita da maioria absoluta nas eleições à presidência, se justificam pela ideia de que era necessário sair da estrita legalidade para conseguir, por fim, mantê-la. ${ }^{6}$

Boa parte da crise passaria pela falta de responsabilidade das elites, únicos atores verdadeiramente conscientes do processo político, incapazes de ordenar, de acordo com as melhores tradições nacionais, o cenário político brasileiro. Tal ausência leva muitos personagens a incidirem em outro erro, respondendo à imoderação dos que buscam "plebeizar" o país, política e moralmente, em tom ainda mais virulento. Bacharéis conservadores, como Afonso Arinos, se distinguem por atribuir um papel moderador às elites, as quais devem figurar acima dos embates políticos. Para o mineiro, o lugar dos verdadeiros líderes, os estadistas, não é nas fronteiras dos que querem a transformação radical do mundo, os partidários do Movimento, ou militando ao lado dos arautos da Reação, integrantes do bloco da Ordem, mas sim, aristotelicamente, no meio entre os extremos, de modo que os permita atuar para o adequado equilíbrio.

O país vivia, aos olhos do bacharel, uma inegável "crise de transformação”, mas as mudanças não se limitam às suas fronteiras. O Ocidente se vê diante da erosão de velhos mantras democráticos, como bem exemplifica a atual "crise do Direito", que demanda novas soluções e a superação de velhos dogmas. O momento, todavia, não seria o de recusar frontalmente as transformações, o que tende a precipitá-las, mas de conseguir dirigi-las. Assumir perante as crescentes demandas sociais postura de confronto ou negação acaba por constituir "um serviço à causa revolucionária, porque facilitar a evolução é impedir a revolução, ao passo que

${ }^{6}$ O ponto é sugerido por famosa interpretação de Wanderley Guilherme dos Santos (1978) e reiterado por Maria Victoria Benevides (1981). 
reprimir o curso natural do progresso é preparar a explosão inevitável das mais justas revoltas" (Franco, 1961, p. 160).

A adesão de Arinos ao parlamentarismo, renegando a consolidada posição que construíra no embate público com Raul Pilla, este um histórico defensor da solução parlamentar, é eloquente demonstração do esforço do bacharel para encontrar uma via mais suave para as mudanças, sem o ritmo abrupto e os riscos inerentes às transformações lideradas por um presidente. As razões da adesão ao novo modelo político foram "colhidas na experiência dos fatos e não na ciência dos livros" (Franco e Pilla, 1999, p. 1) e amparadas "em motivos políticos e não jurídicos” (Franco e Pilla, 1958, p. 13). A experiência que justifica a apostasia passa pela observação de que a "América Latina tende para a forma de governo caudilhista [...] que é menos o sistema em que governa um caudilho do que o regime em que predomina politicamente a força armada" (Franco e Pilla, 1958, p. 7). Os motivos não 298 se apoiam na observação de algumas conjunturas, mas se fundam nos traços culturais da Ibéria. Estão ausentes da realidade brasileira os elementos políticos e culturais que sustentam o presidencialismo norte-americano, o que torna as eleições verdadeiros "plebiscitos entre dois demagogos que se enfrentam periodicamente nas campanhas eleitorais" (Franco e Pilla, 1958, p. 12), as quais fazem o país "caminhar desatinadamente para a anarquia econômica e social e para a ditadura militar consequente" (Franco e Pilla, 1958, p. 12).

O parlamentarismo se coloca, aos olhos de Arinos, como interessante solução para um cenário de descalabro, primeiro por reforçar em terras brasileiras um dos elementos que sustenta a experiência norte-americana, os partidos políticos, mas sobretudo por seu elemento francamente conservador, que o permitirá resistir às três forças que derroem as bases da República brasileira: demagogia, improvisação e corrupção. O parlamentarismo aparece como opção conservadora, necessária para evitar uma catástrofe. Os bacharéis 
revelam, mais uma vez, as facetas do seu liberalismo conservador, desejoso de uma solução por cima.

Os bacharéis modernizantes, por sua vez, aderem com maior vigor ao militarismo. Desde os primeiros momentos o flerte com os homens de armas frequentava o imaginário e unia o partido do brigadeiro. Os ares anticomunistas aumentavam, todavia, a já usual proximidade (Benevides, 1981) e levavam à crescente incitação de um maior protagonismo da Forças Armadas. Os militares eram evocados como reserva de moralidade em uma país imoral e elevados a protagonistas capazes de impedir os processos de corrupção e subversão. Marca de nascença da República brasileira (Carvalho, 2005; Coelho, 2000; Faoro, 2000), o militarismo retornava agora defendido pelos liberais que o combateram à época da Campanha Civilista e surgia aos seus olhos como única saída para a restauração da ordem perdida, mesmo que para isso fosse necessário um golpe. Em discurso de posse na Convenção Nacional da UDN, de 1963, o presidente eleito Bilac Pinto defende sem mediações a ação das Forças Armadas como verdadeiro poder moderador, responsável por não apenas repelir as efetivas tentativas de subversão da ordem, mas por comandar amplas ações preventivas nesse sentido: "Confiamos em que as Forças Armadas, que se destinam a defender a Pátria e a garantir os poderes constituídos, a lei e a ordem, possam interromper o curso visível desse processo revolucionário, restituindo a família brasileira à tranquilidade" (Bilac Pinto, 1963, n.p.).

\section{Considerações finais}

As enormes mudanças que o país vivenciava desde a década de 1920 continuaram a se desenvolver e assumiram forma institucional mais acabada após 1945. O regime democrático ganhou estabilidade e amplitude até então inéditas, em claro processo de democratização, mesmo persistindo a exclusão dos analfabetos e, após 1947, do partido 
comunista. O país mudara e o exercício do voto por um contingente tão amplo de indivíduos tinha, mesmo com todas as ponderações necessárias, amplas consequências políticas. Com o crescente fortalecimento das forças de esquerda e o aumento da participação das massas, o olhar para o jurídico mediado pela moral, com seu forte acento elitista, parece em descompasso com o clima da época, em cenário no qual a "banda de música" por vezes soa como reminiscência de outro país. As seguidas derrotas eleitorais da UDN nas eleições presidenciais levam outras forças udenistas a questionarem a eficácia das disputas em torno do jurídico, assim como a retórica bacharelesca que caracterizava o partido, em disputa que irá transformá-lo de forma decisiva.

A oposição, evidentemente problemática, entre uma UDN pura em seu princípio e outra decaída, ao fim da República de 1946, importa menos do que a percepção sobre o ocaso dos bacharéis no partido e na política brasi300 leira da época. A interpretação é aguda nesse ponto. A história do partido e da República de 1946 se caracteriza, de fato, por um constante declínio da influência dos célebres juristas, em que pese a pompa dos seus discursos, em oposição à ascensão de outros grupos dentro do partido e do campo liberal (Benevides, 1981). A decadência atinge sobretudo os bacharéis conservadores, que se veem progressivamente alheados do centro do poder. Eles aderem ao golpe - responsável por criar um mundo ainda mais estranho aos seus valores - de forma subalterna para, posteriormente, se afastarem dos cimos do poder.

Os bacharéis modernizantes já haviam se aproximado, na leitura dos caminhos a serem seguidos, da onda lacerdista que varreria o partido. Bilac e Baleeiro comungavam da agressividade anticomunista e transitavam com maior desembaraço pelo mundo do interesse. Outros grupos udenistas também flertam com o político carioca, como os "realistas" e os atores mais próximos da grande burguesia 
nacional, caso de Herbert Levy, os quais passam a considerar que o estilo agressivo e a ausência de qualquer cerimônia perante as instituições democrática tornam Lacerda mais versado nos meandros democráticos, e golpistas, do que os bacharéis, estes vistos como excessivamente formalistas, mesmo quando era necessário justificar soluções ilícitas. Menos hábeis para lidar com as vicissitudes do novo tempo, os bacharéis perdem espaço para o governador da Guanabara, que melhor manejaria a linguagem e as exigências da política de massas.

\section{Jorge Gomes de Souza Chaloub}

é doutor em Ciência Política pelo Instituto de Estudos Sociais e Políticos da Universidade do Estado do Rio de Janeiro (IespUerj) e professor do Departamento de Ciências Sociais e do Programa de Pós-Graduação em Ciências Sociais (PPGCSO) da UFJF.

\section{Bibliografia}

ADORNO, Sergio. 1988. Os aprendizes do poder: o bacharelismo liberal na política brasileira. Rio de Janeiro: Paz e Terra.

AGUIAR, Thais Florencio. 2013. Uma genealogia de princípios de demofilia em concepções utópicas de democratização. Tese de Doutorado em Ciência Política. Rio de Janeiro: Uerj.

ARRUDA, Maria Arminda do Nascimento. 1990. Mitologia da mineiridade o imaginário mineiro na vida política e cultural do Brasil. São Paulo: Brasiliense.

AUDAR, Catherine. 2009. Qu'est-ce que le libéralisme: éthique, politique, société. Paris: Gallimard.

BALEEIRO, Aliomar. 1952a. Diário. In: Arquivo Aliomar Baleeiro. Rio de Janeiro: CPDOC-FGV.

BALEEIRO, Aliomar. 1952b. Rui, um estadista no Ministério da Fazenda. Rio de Janeiro: Casa de Rui Barbosa.

BALIBAR, Etienne. 1997. La Crainte des Masses: Politique et Philosophie avant et après Marx. Paris: Galilée. (Collection La Philosophie en effet).

BANDEIRA, Manuel. Estrela da vida inteira. Rio de Janeiro: José Olympio, 1986.

BARBOSA, Rui. 1952. Obras Seletas. Rio de Janeiro: Casa de Rui Barbosa. 
BARBOZA FILHO, Rubem. 2000. Tradição e artifício: iberismo e barroco na formação americana. Belo Horizonte: Editora UFMG.

BENEVIDES, Maria Victoria de Mesquita. 1981. A UDN e o udenismo: ambiguidades do liberalismo brasileiro. Rio de Janeiro: Paz e Terra.

BILAC PINTO, Olavo. 1953a. Estudos de Direito Público. Rio de Janeiro: Forense.

BILAC PINTO, Olavo. 1953b. O declínio das sociedades de economia mista e o advento das modernas empresas públicas. Revista de Direito Administrativo, v. 32, pp. 1-15.

BILAC PINTO, Olavo. 1963. Discurso de posse na presidência da UDN. In: Arquivo UDN. Rio de Janeiro: IHGB.

BILAC PINTO, Olavo. 1964. Guerra Revolucionária. Rio de Janeiro: Forense.

BROWN, Wendy. 2015. Undoing the Demos: Neoliberalism's Stealth Revolution. New York: Zone Books.

CAMARGO, Aspásia (org.). 1983. O intelectual e o político: encontros com Afonso Arinos. Brasília, DF: Senado Federal.

CAMPOS, Milton. 1951. Compromisso Democrático. Belo Horizonte: Secretaria da Educação do Estado de Minas Gerais.

CAMPOS, Milton. 1972. Testemunhos e Ensinamentos. Rio de Janeiro: José Olympio.

302 CARVALHO, Jose Murilo. 2005. Forças armadas e política no Brasil. Rio de Janeiro: Zahar.

CHALOUB, Jorge. 2017. A economia política dos bacharéis udenistas. Revista Brasileira de Ciências Sociais, v. 32, n. 94, pp. e329406.

COELHO, Edmundo Campos. 1999. As profissões imperiais: medicina, engenharia e advocacia no Rio de Janeiro, 1822-1930. Rio de Janeiro: Record.

COELHO, Edmundo Campos. 2000. Em busca de identidade: o exército e a política na sociedade brasileira. Rio de Janeiro: Record.

DULCI, Otávio Soares. 1986. A UDN e o anti-populismo no Brasil. Belo Horizonte: Editora UFMG; Proed.

ENGELMANN, Fabiano. 2006. Sociologia do campo jurídico. Porto Alegre: Sérgio Fabris.

FAORO, Raymundo. 2000. Os donos do poder: a formação do patronato político brasileiro. São Paulo: Globo.

FERNANDES, Florestan. 2006. A revolução burguesa no Brasil: ensaio de interpretação sociológica. São Paulo: Globo Livros.

FRANCO, Afonso Arinos de Melo. 1953. Discurso 16 jan. 1953. In: BRASIL. Diário do Congresso Nacional. Brasília, DF: Câmara dos Deputados.

FRANCO, Afonso Arinos de Melo. 1954. Discurso 09 ago. 1954. In: BRASIL. Diário do Congresso Nacional. Brasília, DF: Câmara dos Deputados. 
FRANCO, Afonso Arinos de Melo. 1961. Estudos e Discursos. São Paulo: Editora Comercial.

FRANCO, Afonso Arinos de Melo. 1965. A escalada: memórias vol. 2. Rio de Janeiro: José Olympio.

FRANCO, Afonso Arinos de Melo. 1968. Planalto: memórias vol. 3. Rio de Janeiro: José Olympio.

FRANCO, Afonso Arinos de Melo. 1976. Prefácio. In: VIANA FILHO, Luís. Juarez Távora: uma vida e muitas lutas: memórias. Rio de Janeiro: Biblioteca do Exército. V. 2, pp. I-XII.

FRANCO, Afonso Arinos de Melo. 1980. História e teoria dos partidos políticos no Brasil. São Paulo: Alfa-Ômega.

FRANCO, Afonso Arinos de Melo. 2005. A Evolução da Crise brasileira. Rio de Janeiro: Topbooks.

FRANCO, Afonso Arinos de Melo; PILLA, Raul. 1999. Presidencialismo ou parlamentarismo? Rio de Janeiro: José Olympio.

FRANCO, Virgílio de Mello. 1946. A campanha da UDN (1944-1945). Rio de Janeiro: Zélio Valverde.

HOLLANDA, Cristina Buarque de; CHALOUB, Jorge. 2017. Rui Barbosa em disputa: a memória política na República de 1946. Novos estudos CEBRAP, v. 36, n. 3, pp. 99-126.

KELLY, José Eduardo do Prado. 1977. O fascínio da democracia. Rio de Janeiro: Agir.

LACLAU, Ernesto. 2013. A razão populista. São Paulo: Três Estrelas.

LATTMAN-WELTMAN, Fernando. 2005. A Política Domesticada: Afonso Arinos e o colapso da democracia em 1964. Rio de Janeiro: Editora FGV. LYNCH, Christian Edward Cyril. 2011. Do despotismo da gentalha à democracia da gravata lavada: história do conceito de democracia no Brasil (1770-1870). Dados, v. 54, n. 3, pp. 355-390.

MAUSS, Marcel. 2003. Sociologia e Antropologia. São Paulo: Cosac Naify. MICELI, Sergio. 1997. Carne e osso da elite política brasileira pós-1930. In: HOLANDA, Sergio Buarque de; FAUSTO, Boris. História geral da civilização brasileira: sociedade e política (1930-1964). Rio de Janeiro: Bertrand Brasil. t. 3, V. 10, pp. 661-710.

MOTTA, Rodrigo Patto Sá. 2002. Em guarda contra o "perigo vermelho": o anticomunismo no Brasil, 1917-1964. São Paulo: Perspectiva.

ROSANVALLON, Pierre. 2002. O liberalismo econômico: história da ideia de mercado. Bauru: Edusc.

SANTOS, Wanderley Guilherme dos. 1978. Ordem Burguesa e Liberalismo Político. Rio de Janeiro: Duas Cidades. 
SCHWARZ, Roberto. 2000. Ao vencedor as batatas: forma literária e processo social nos inicios do romance brasileiro. São Paulo: Duas Cidades.

SOARES, Gláucio Ary Dillon. 2001. A democracia interrompida. Rio de Janeiro: Editora FGV.

TILLY, Charles. 2006. Democracia. Petrópolis: Vozes.

TOCQUEVILLE, Alexis de. 2001. Democracia na América. São Paulo: Martins Fontes. V. 1, 2.

VENANCIO FILHO, Alberto. 2004. Das arcadas ao bacharelismo: 150 anos de ensino jurídico no Brasil. São Paulo: Perspectiva.

VIANNA, Luiz Werneck. 1976. Liberalismo e sindicato no Brasil. São Paulo: Paz e Terra.

VIANNA, Luiz Werneck. 1986. Travessia: da abertura à Constituinte. Rio de Janeiro: Taurus.

VIANNA, Luiz Werneck. 2001. O Estado Novo e a expansão autoritária da República. In: CARVALHO, Maria Alice Rezende. República no Catete. Rio de Janeiro: Museu da República. pp. 27-61.

VIANNA, Luiz Werneck. 2004. A revolução passiva: iberismo e americanismo no Brasil. Rio de Janeiro: Revan.

VILLEY. Michel. 2008. A formação do pensamento jurídico moderno. São Paulo: Martins Fontes.

304 WEBER, Max. 2004. Economia e sociedade: fundamentos da sociologia compreensiva. Brasília, DF: Editora UnB; Imprensa Oficial. V. 1. 


\section{O BRASIL DOS BACHARÉIS: UM DISCURSO LIBERAL UDENISTA}

JORGE GOMES DE SOUZA CHALOUB

Resumo: Este artigo reconstrói as principais teses e influências intelectuais dos bacharéis udenistas, tratando do pensamento político de personagens como Afonso Arinos, Bilac Pinto, Aliomar Baleeiro, Milton Campos e Prado Kelly. Para a tarefa, são mobilizados escritos jurídicos, memórias, discursos parlamentares e outras reflexões que permitam caracterizar esse pensamento que é voltado à ação, mas que também é expressão de uma visão de mundo transcendente à disputa política mais imediata. $\mathrm{O}$ texto se divide em três partes. Na primeira, trata da autoimagem dos bacharéis em oposição à categoria antagônica dos juristas, e distingue dois tipos ideais: os conservadores e os modernizantes. A segunda seção aborda o tipo de liberalismo dos bacharéis, visto como chave para a compreensão das suas trajetórias. Por fim, o trabalho se concentra nos argumentos dos autores sobre as relações entre elites e direito, com o intuito de melhor compreender o sentido da sua missão política e das suas trajetórias ao longo da República de 1946.

Palavras chave: UDN; Bacharéis; Juristas; Liberalismo; República de 1946.

\section{BRAZIL IN THE VIEW OF BACHELORS OF LAW: UDN'S LIBERAL DISCOURSE}

Abstract: The article exposes the main arguments and intellectual influences of UDN's bachelors. In this effort, it presents the political thought of public actors like Afonso Arinos, Bilac Pinto, Aliomar Baleeiro, Milton Campos and Prado Kelly. For this task, it analyses juridical writings, parliamentary speeches, memories and other intellectual writings for a comprehensive view of this thought which is linked to action but is also an expression of a more transcendent worldview. The article is divided in three parts. Firstly, it exposes the self-image of bachelors, opposed to the concept of jurists, and 
distinguishes two ideal types: the modernizers and the conservatives. The second section argues the relevance of liberal discourse in their political decisions. Finally, the work analyses the relation between elites and law in their arguments, with the purpose of better understand the political mission of these actors and their trajectories during the Republic of 1946.

Keywords: UDN; Bachelors; Jurists; Liberalism; Republic of 1946.

Recebido: 22/12/2017 Aprovado: 28/05/2019 